\title{
CORRESPONDENCE
}

\section{Pay as you go}

SIR-Although far more interesting and important things are now happening in Poland, let me bring to your attention one more Polish subject connected with the Polish regime's abuses of decency or simply the law. Every Polish scientist going abroad for professional purposes, and for a long period, is forced to sign a declaration. ("Long period" means more than eleven weeks. Why just eleven? - Nobody knows.)

The declaration is an obligation to pay some arbitrarily fixed sum of money every month to the so-called "hard currency scholarship fund", created apparently to finance foreign trips for some unspecified persons. The point is that although many Polish scientists were forced to, and did, pay their money to the fund, no-one has ever heard of anyone actually getting something from this fund. There are rumours that the money is being used to finance "study" trips for Polish journalsts, for example to the United States, where they use the American money to collect materials for painting the American system in black colours. Indeed, the fund in question is under no form of public control, and no-one really knows to what purpose the money is used. The character of the deal comes out most clearly from this paragraph in the declaration:

"If the currency regulations of the country where I shall be staying would make it impossible to send my contribution to the hard-currency scholarship fund via a bank, I undertake to send the remittance to the nearest agency of the Polish People's

Republic abroad."

As you are aware of the political situation in Poland I hope that you will understand my request to keep my name, and address a secret.

Name and address withheld - ED, Nalure

\section{Nuclear power costs}

SIR - The Central Electricity Generating Board (CEGB) is to be congratulated on providing more details of its cost comparisons for the different power station types. As it emphasizes in its report, current relative economic performance of coal and nuclear systems is not an adequate guide to future investment decisions. However, one could argue that operating experience is a guide to future technical (rather than economic) performance. Load factors are one measure of technical performance, and your report made some pertinent observations regarding the reported load factors of power stations operated and planned by the CEGB (Nature 21 August, p.753), Obviously the cost per kWh per annum is sensitive to the load factor and it is informative to recalculate the predicted generating costs of possible future nuclear and coal power stations using load factors consistent with those quoted for existing stations. The table summarizes factors on design output given in the CEGB report load.

$\begin{array}{lcc} & \text { Nuclear } & \text { Coal } \\ \text { Stations (1965-77) } & 56 \% & 61 \% \\ \text { Hinkley B; Drax I } & 43 \% & 73 \% \\ \text { Stations under construction } & 49 \% & 56 \% \\ \text { Futurc stations } & 63 \% & 54 \%\end{array}$

The figures show an unexplained optimism for nuclear systems and a corresponding pessimism for coal systems. Assuming load factors consistent with experience (say $70 \%$ for coal and $50 \%$ for nuclear) reverses and predicted cost ranking for the fuels in question. Specifically, nuclear comes out some $8 \%$ more expensive than coal $(2.8 \mathrm{p}$ per $\mathrm{kWh}$ compared with $2.6 \mathrm{p}$ per $\mathrm{kWh}$ ) rather than $35 \%$ cheaper as derived by the CEGB.

Department of Physics,

RICHARD MARSHALL University of Keele, $U K$

\section{Why examine?}

SIR-It was interesting to read the article on school examinations (Nature 3 July p.2). As one who, although born and educated in the United Kingdom, has spent most of my working life teaching overseas, my usual plaint is that the schools we have to deal with do not teach $\mathrm{A}$ levels and that it is so much better in the UK where they do. The main reason why the schools I know do not teach A levels is not choice, but simply lack of qualified teachers.

As in everything else, there are pros and cons and things look different from the other side of the fence. One thing I am convinced of, however, is that good schools are much better at teaching $\mathrm{A}$-level material than are universities. In general, university staff do not make good school teachers.

\section{Department of Chemistry}

D.A.H. TAYLOR

University of Natal,

Durban, South Africa

\section{Third World matters}

SIR-" "Pesticides in developing countries" (Nature 28 August p.832) was a patronizing editorial on the New Internationalist; a journal that is not a "citadel for extreme environmentalists" but a medium for exposing injustice, stimulating debate and campaigning for and on behalf of the poor of the Third World.

Transnational corporations are mostly the villains because it is often their trading practices that accentuate North-South differences. Global profit maximization policies tend not to be compatible with the needs of the people of the Third World. For example, infant mortality rates have increased significantly in areas where advertising has persuaded mothers to abandon breast feeding for Nestle milk powder products. Other cases are more insidious: uncontrolled marketing of harmful products, including cigarettes and pesticides. High blood levels of DDT $(30 \times$ that in USA) being the corollary of one aggressive marketing campaign in Guatemala.

New Internationalist is not a scientific journal. It does try to report facts accurately and from an objective stance. This is expected of Nature. It was unfortunate that a basic, scientific definition had to be distorted in order to accommodate editorial views: DDT is a poison, a poison being a substance that when introduced into or absorbed by a living organism (or ecosystem) destroys life or injures health.
May I reiterate Clive Jenkins' final point (Nature 21 August p.754) that Nature should abandon prejudice and support quite reasonable crusades to protect people.

Department of Genetics,

Peter Clarke

University of Edinburgh,

Edinburgh, UK

\section{Felig replies}

SIR, - Your account of the events surrounding my resignation from Columbia University (Nature, 21 August) contains a number of inaccuracies and omissions which may lead the reader to a distorted view of this unfortunate affair.

Firstly, my proposal that Dr Soman be considered for a faculty appointment at Columbia occurred in January rather than February 1980, before the first audit which revealed data falsification by Dr Soman. Secondly, the letter by Soman in February 1980 , declaring his responsibility for the similarities to the paper from the Roth laboratory and for "fudging"' data, was not written at my request but was his own effort to "set the record straight" at the time of his resignation. Dr Soman had, in fact, admitted in March 1979 that he had retained a copy of the Wachslicht-Rodbard manuscript and had used parts of it to prepare his own manuscript. At that time he was severely reprimanded and steps were taken to assure Roth's priority.

Thirdly, the delay in obtaining the first audit was a result of the failure of the agreed upon auditor (Dr Edward Rall) to follow through with his offer to come to Yale and review the original data. Fourthly, while Dr Roth is quoted as considering it "careless" for us to allow publication of our paper pending an audit, he had in fact written to us on 5 March 1979 that "I hope you will go on to have your fine and original piece of research published appropriately". Fifthly, those papers which were considered questionable after the second audit involved studies for which original data were not available for audit because Dr Soman (by his written admission) had destroyed the original notebooks. Sixthly, in addition to informing Dean Tapley on 27 February 1980, I met with five of the senior faculty in the Department of Medicine at Columbia in May 1980 , prior to my assuming the Chairmanship, and informed them of Soman's data falsification and that $I$ would be sending letters of retraction to journals.

Finally, your article fails to take note of the fact that at the time the paper on anorexia nervosa was submitted for publication by Soman and myself, Soman was in his third year of a faculty appointment at Yale, had extensive independent grant support, was responsible for his own laboratory and was highly regarded by all his colleagues. Any retrospective analysis of the handling of his wrongdoing in using the Wachslicht-Rodbard manuscript to prepare his own must be viewed in that context.

New Haven, Connecticut 06510 